\title{
PENTINGNYA KOMPETENSI PEDAGOGIK GURU
}

\author{
Aulia Akbar ${ }^{1}$ \\ STKIP Sebelas April Sumedang \\ 1akbaraulia224@gmail.com
}

\begin{abstract}
ABSTRAK
Kualitas seoang guru dapat diukur dari seberapa besar guru menguasai empat kompetensi yang ada. Keempat kompetensi tersebut yaitu: kompetensi pedagogik, kompetensi sosial, kompetensi profesional, dan kompetensi keperibadian. Dalam praktiknya da satu kompetensi yang membedakan antara guru dan profesi lainnya yaitu kompetensi pedagogik. Kompetensi pedagogik merupakan kompetensi yang mutlak dimiliki oleh guru sekaligus kompetensi ini merupakan kompetensi yang membedakan guru dengan profesi lainnya. Kompetensi ini mencakup pengetahuan dan keterampilan yang luas serta mendalam mengenai karakteristik siswa serta psikologi siswa. dengan menguasai kompetensi ini diharapkan guru dapat lebih efektif dan efisien dalm berinteraksi dengan siswa serta dapat memacahakan permasalahan yang terjadi pada siswa. Agar dapat mengembangkan diri, seorang guru harus selalu mengasah pengetahuan dan keterampilan menganai pembelajaran dan siswa. beberapa cara yang dapat dilakukan guru dalam mengasah kemempuannya yaitu: rajin rmembaca buku-buku pendidikan, membaca dan menulis karya tulis ilmiah, mengikuti berita aktual dari media pemberitaan, serta mengikuti pelatihan.
\end{abstract}

Kata kunci: Kompetensi, Pedagogik, Guru

\begin{abstract}
The quality of a teacher can be measured by how much the teacher has mastered the four existing competencies. The four competencies are: pedagogical competence, social competence, professional competence, and personal competence. In practice, there is one competency that distinguishes teachers and other professions, namely pedagogical competence. Pedagogic competence is a competency that is absolutely possessed by teachers as well as this competency that differentiates teachers from other professions. These competencies include broad and in-depth knowledge and skills regarding student characteristics and student psychology. By mastering this competency, it is hoped that the teacher can be more effective and efficient in interacting with students and can solve problems that occur to students.In order to develop themselves, a teacher must always hone knowledge and skills regarding learning and students. There are several ways that teachers can hone their skills, namely: diligently reading educational books, reading and writing scientific papers, following actual news from the news media, and attending training.
\end{abstract}

Key words: Competence, pedagogy, teacher 


\section{PENDAHULUAN}

Guru merupakan salah satu profesi yang mulia dan terhormat. Gurulah yang memegang kendali dalam mencetak peradaban dan kemajuan suatu generasi. Begitu pentingnya peranan seorang guru telah dibuktikan kaisar Jepang pada masa perang saat melawan sekutu, dimana ketika dua kota terbesar di negara Jepang yaitu, Hirosima dan Nagasaki di bom atom oleh sekutu yang menewaskan mayoritas penduduknya. Ketika bencan aitu terjadi ada hal yang paling penting ditanyakan oleh kaisar pada waktu itu adalah "berapa orang guru yang tersisa". Hal imi membuktikan peranan guru yang sangat besar bagi kemajuan suatu negara.

Dibalik pentingnya peranan seorang guru bagi kemajuan suatu bangsa terselip tanggung jawab yang tidak mudah. Guru diharapkan mampu mengenguasai berbagai keterapilan-keterampilan yang dibutuhkan dalam rangka menjadikan profesi guru menjadi profesional. Dalam sistem pendidikan di Indonesia telah diatur kompetensi yang harus dimiliki oleh guru dalam menjalankan kewajibannya. Kompetensi berasal dari kata competency, suatu kemampuan atau kecakapan yang dimiliki oleh seseorang dalam melaksanakan suatu pekerjaan atau tugas di bidang tertentu, sesuai dengan jabatan yang disandangnya. Pada hakikatnya kompetensi merupakan gambaran mengenai terampilnya seseorang dalam melakukan suatu kegiatan atau tugas yang diembannya secara nyata dan dapat diukur dengan pasti. Undang-undang Republik Indonesia Nomor 14 Tahun 2005 tentang Guru dan Dosen, dijelaskan bahwa, kompetensi adalah seperangkat pengetahuan, keterampilan, dan perilaku yang harus dimiliki, dihayati, dan dikuasai oleh guru atau dosen dalam melaksanakan tugas keprofesionalan (Mulyasa, 2013:25). Undang-undang Guru dan Dosen No.14/2005 Pasal 10 ayat 1 Dan Peraturan Pemerintah No.19/2005 pasal 28 ayat 3 juga menyatakan hal yang sama hal tersebut diungkapkan Suprihatiningrum (2014:100) menyatakan bahwa, kompetensi guru meliputi kompetensi pedagogik, kompetensi kepribadian, kompetensi sosial dan kompetensi profesional. Keempat kompetensi tersebut memiliki berbagai indikator/komponen tersendiri, namuan keseluruh indikator/komponen memiliki keterkaitan yang erat antara satu dengan yang lainnya. Berdasarkan pendapat di atas maka dapat di katakan syarat agar guru menjadi guru yang profesional hauslah menguasai ke empat keterampilan tersebut. Empat pilar ini yang menjadi bekal dalam membangkitkan kualitas pendidikan di Indonesia. Menurut Saud (2010: 50), ada sepuluh kompetensi yang harus dimiliki seorang guru, yaitu:

1. Menguasai bahan

2. Mengelola program belajar-mengajar

3. Mengelola kelas

4. Menggunakan media atau sumber belajar

5. Menguasai landasan pendidikan

6. Mengelola interaksi belajar-mengajar

7. Menilai prestasi belajar

8. Mengenal fungsi dan layanan bimbingan penyuluhan

9. Mengenal dan menyelenggarakan administrasi sekolah 
10. Memahami dan menafsirkan hasil penelitian guna keperluan pelajaran.

Beberapa kompetensi tersebut di atas dapat diterapkan dalam kegiatan belajar mengajar di dalam kelas. Menurut Kusnandar (2009: 57) bahwa keterampilan mengajar adalah sejumlah kompetensi guru yang menampilkan kinerjanya secara profesional. Keterampilan tersebut dapat menunjukan jati diri seorang guru dalam melaksanakan tugasnya. Beberapa prilaku tersebut dapat ditampilkan di antaranya.

1. Keterampilan membuka pembelajaran, dalam memulai suatu proses pembelajaran pembukaan merupakan hal yang sangat penting. Pembukaan yang baik dan menarik akan membuat peserta didika antusias dalam menyimak dan ikut berpartisipsi dalam Kegiatan pembelajaran. Selain itu, kegiatan pembuka pelajaran juga dapat dimanfaatkan guru dalam melakukan apersepsi, kegiatan ini membantu sisiwa dalam menghubungkan konsep yang lalu/ yang didapat siswa dalam kehidupan sehari-hari dengan konsep yang akan diberikan guru.

Sebagai contoh, ketika guru akan menyampaikan materi menganai gaya tarik bumi, maka guru dapat menanyakan kepada siswa apakah pernah melihat daun yang jatuh dari cabang pohon.

2. Keterampilan menutup pembelajaran, menutup pembelajaran merupakan kegiatan yang harus diperhatikan guru. Kegiatan ini harus dilakukan dengan baik yang bertujuan untuk mempertahankan mood sisiwa dalam menerima pembelajaran selanjutnya. Kegiatan ini juga dapat dimanfaatkan guru untuk mengevaluasi sejauh mana materi pembelajaran diserap oleh siswa. selain itu, keterampilan ini dapat digunakan guru untuk memberikan penguatan materi berupa menyimpulkan hasil kegiatan pembelajaran yang telah dilakukan. Sebagai contoh, guru dapat menyimpulkan bersama siswa mengenai inti dari materi yang dipelajari.

3. Keterampilan menjelaskan, keterampilan menjelaskan adalah kemampuan yang mutlak dikuasai oleh guru, dengan adanya kemampuan ini siswa dapat lebih menguasai materi pembelajaran yang diberikan. Keterampilan ini haruslah terus dikembangkan agar terciptanya komunikasi dua arah yang efektif dan efisien. Komunikasi yang baik antar guru dan siswa akan menciptakan kelas yang aktif dan komunikatif sehingga melahirkan kreativitas. Sebagai contoh, guru dapat menjelaskan suatu konsep dengan memberikan penekanan pada konsep-konsep yang dirasa penting untuk disampaikan dan memberikan variasi suara agar siswa tidak jenuh dalam menyimak materi yang disampaikan.

4. Keterampilan mengelola kelas, keterampilan selanjutnya adalah keterampilan pengelolaan kelas, dimana dengan guru menguasai ketrampilan ini akan membantu guru dalam menciptakan kelas yang kondusif. Bila dilakukan dengan baik dapat membantu pencapaian prestasi siswa. sebagai contoh, guru dapat menampatkan siswa yang menonjol dengan siswa yang 
biasa, hal ini dilakukan agar siswa yang menonjol di kelas dapat membantu siswa lain dalam kegiatan pembelajaran, kegiatan ini dikenal dengan nama kegiatan "tutor sebaya".

5. Keterampilan bertanya, ketrampilan ini harus dimiliki seorang guru. keterampilan ini merupakan keterampilan yang dapat menjadi modal guru dalam mengevaluasi pembelajaran. Selain itu, keterampilan ini juga dapat membangkitkan keberanian siswa untuk dapat berpendapat yang akan memberi pengaruh pada rasa percaya diri siswa. namun demikian, guru haruslah dapat memilah dan memilih pertanyaan sesuai dengan tingkat pemahaman siswa perindividu. Pertanyaan yang mudah diberikan pada siswa yang agak lambat dalam menangkap pembelajaran dan sebaliknya. Sebagai contoh, guru dapat memberikan pertanyaan yang sifatnya hafalan dan jawaban singkat pada siswa yang dirasa lambat, dan guru dapat bertanya dengan pemahaman untuk siswa yang cepat dalam menangkap pembelajaran.

6. Keterampilan memberi penguatan, bila dikuasai dengan baik keterampilan ini akan dapat memberikan pengarus besar dan positif pada siswa. Keterampilan ini dapat dimanfaatkan guru tidak hanya untuk membuat siswa lebih paham terhadap konsep yang terlah diberikan namun juga dapat dimanfaatkan untuk menumbuhkan karakter yang baikuntuk siswa. sebagai contoh, bila siswa menjawab dengan jujur berikan tepuk tangan atau pujian. Hal tersebut akan menjadikan siswa tersebut percaya diri dan mampunyai keberanian untuk tampil karena siswa merasa dihargai.

7. Keterampilan memberi variasi, dengan guru memiliki keterampilan memberi variasi kegiatan pembelajaran akan dapat mengatasi kejenuhan yang terjadi dikala proses belajar mengajar. Memberikan variasi pada saat membelajaran bisa bermacam-macam bentuknya, misalnya: variasi dalam menggunakan metode pembelajaran, variasi dalam Gerakan badan dan mimik, variasi dalam pergerakan guru ketika mengajar, variasi dalam bersuara dll. Sebagai contoh, dalam pembelajaran mendongeng guru meninggikan atau merendahkan suara sesuai dengan karakter tokoh yang ada pada dongeng.

Dengan guru memiliki beberapa keterampilan di atas maka dapat menjadikan guru profesional di bidangnya. Keterampilan ini merupakan keterampilan yang dibutuhkan guru dalam mengajar di kelas.

Salah satu kompetensi yang mutlak dan yang menajadi pembeda antara guru dengan profesi lainnya adalah kompetensi pedagogik. Kompetensi pedagogik ini berisi kecakapan-kecakapan yang dibutuhkan seorang guru agar menjadi guru yang profesional. 


\section{PEMBAHASAN}

Secara etimologis kata pedagogi berasal dari kata bahasa Yunani, paedos dan agagos (paedos=anak dan agage = mengantar atau membimbing) karena itu pedagogi berarti membimbing anak. Membimbing dalam arti memberikan moral, pengetahuan serta keterampilan kepada siswa. Dalam kaitannya dengan pembelajaran di kelas, kompetensi pedagogis ini merupakan bekal bagi seorang guru dalam memasuki dunia pendidikan yang sekaligus dalam peraktiknya berhubungan erat dengan siswa.

Siswa merupakan individu yang belum matang secara fisik dan mental, maka perlu adanya bimbingan dari orang dewasa dalam mempelajari berbagai hal baik dalam lingkungan sosial, spiritual, dan alam. Kompetensi pedagogik merupakan kemampuan guru yang berkenaan dengan pemahaman terhadap peserta didik dan pengelolaan pembelajaran yang mendidik dan dialogis. Secara substantif, kompetensi pedagogik ini menuntut agar seorang guru dapat memahami perkembangan peserta didik, memahami menganai perancangan pembelajaran serta memahami bagimana pelaksanaan pembelajaran, memahami bagaimana evaluasi pembelajaran, serta memahami bagaimana peserta didik mengaktualisasikan potensi-potensi yang dimiliki siswa. Tidak mengherankan bila kompetensi ini dianggap sebagai kompetensi yang bersifat praktik dimana guru sebagai seorang yang berinteraksi langsung dengan siswa mampunyai peran ganda tidak hanya sebagai pengajar namun sekaligus menjadi pendidik. Berdasarkan penelitian yang dilakukan Sari, Z. I., \& Noe, W (2014: 52) Kompetensi pedagogik merupakan kompetensi yang mempunyai kaitan yang sangat erat dengan kinerja seorang guru. Hal ini didukung dengan hasil penelitian yang menunjukkan bahwa hubungan kompetensi pedagogik dengan kinerja mengajar guru yakni sebesar $46,7 \%$, hal ini berarti bahwa semakin tinggi kompetensi pedagogik guru maka semakin tinggi pula kinerja guru dalam mengajar.

Menurut Meutia, dkk. (2013: 20) Diantara keempat kompetensi tersebut terdapat satu kompetensi yang membedakan guru dengan bidang profesi lainnya, yakni kompetensi pedagogik. Seorang guru harus memiliki kompetensi pedagogik, dimana seorang guru memiliki kemampuan dalam melaksanakan pembelajaran, baik dalam mengelola, melaksanakan pembelajaran dan melakukan evaluasi pembelajaran. Kompetensi pedagogik ini menuntut seorang guru dalam memahami berbagai aspek dalam diri siswa yang berhubungan dengan pembelajaran, adapun kompetensi pedagogik tersebut meliputi:

1. Menguasai karakteristik peserta didik dari aspek fisik, moral, sosial, kultural, emosional, dan intelektual.

2. Menguasai teori belajar dan prinsip-prinsip pembelajaran yang mendidik.

3. Mengembangkan kurikulum yang terkait dengan mata pelajaran/bidang pengembangan yang diampu.

4. Menyelenggarakan pembelajaran yang mendidik.

5. Memanfaatkan teknologi informasi dan komunikasi untuk kepentingan pembelajaran. 
6. Memfasilitasi pengembangan potensi peserta didik untuk mengaktualisasi berbagai potensi yang dimiliki.

7. Berkomunikasi secara efektif, empatik, dan santun dengan peserta didik.

8. Menyelenggarakan penilaian dan evaluasi untuk kepentingan pembelajaran.

9. Melakukan tindakan reflektif untuk meningkatkan kualitas pembelajaran (Wahyudi: 2012: 22).

Menguatkan pemaparan di atas Permendiknas No.16 Tahun 2007 tentang Standar pendidik dan Kependidikan memaparkan bahwa, kompetensi pedagogik merupakan kemampuan guru dalam pengelolaan pembelajaran siswa yang sekurangkurangnya meliputi hal-hal sebagai berikut (Suprihatiningrum, 2014:101-103):

1. Pemahaman wawasan atau landasan kependidikan (kemampuan mengelola pembelajaran)

2. Pemahaman terhadap peserta didik

3. Perancangan pembelajaran

4. Pelaksanaan pembelajaran yang mendidik dan dialogis

5. Pemanfaatan teknologi pembelajaran

6. Evaluasi hasil belajar

7. Pengembangan peserta didik untuk mengaktualisasikan berbagai potensi yang dimilikinya.

Berdasarkan beberapa pendapat ahli di atas dapat disimpulkan kompetensi pedagogik merupakan kompetensi yang harus kuasai oleh guru dalam menjalankan tugasnya. Kompetensi ini merupakan kompetensi yang membedakan guru dengan profesi lainnya. Maka dari itu, seorang guru mutlak menguasai kompetensi pedagogik.

Begitu penting eksistensi kompetensi pedagogik bagi sorang guru hingga kualitas dari seorang guru dapat diukur sejauh mana penguasaan kompetensi tersebut. Maka dari itu seorang guru haruslah terus mengambangkan kompetensi yang ada pada dirinya. Pengembangan kompetensi menurut (Asmarani, 2014: 504-505) dapat dilakukan dengan cara berikut.

\section{a. Rajin Membaca Buku-Buku Pendidikan}

Tidak dapat disangkal bahwa buku adalah gudangnya ilmu sekaligus melalui jendela dunia. Dengan membaca seseorang dapat mengerti dan memahami suatu materi maupun permasalahan. Guru sebagai seorang yang selalu berinteraksi dengan siswa yang selalu berkembang seyogyanya terus mengembangkan pengetahuan. Hal ini sangatlah penting karena dengan membaca guru dapat mengerti permasalahan yang terjadi pada siswa serta mengetahui bagaimana pemecahannya. Dengan membaca buku-buku pendidikan terutama yang berhubungan pembelajaran mulai dari penguasaan karakteristik peserta didik dari aspek fisik, moral, sosial, kultural, emosional, dan intelektual, terori belajar, kurikulum, teknologi pembelajaran, yang menjadikan pembelajaran lebih efektif dan efisien.. 


\section{b. Membaca dan Menulis Karya Ilmiah}

Membaca dan menulis karya ilmiah merupakan kegiatan yang perlu dilakukan oleh seorang guru dimana dengan membacan dan menulis karya ilmiah akan dapat memperluas dan memperdalam pengatahuan guru akan suatu bidang permasalahan yang dihadapinya. Dengan menulis juga dapat mengasah daya nalar sehingga lebih peka terhadap permasalahan yang terjadi, selain itu dengan menulis karya ilmiah dapat menmbah pengalaman dalam memperdalam keterampilan guru menyusun rancangan pembelajaran secara sistematis.

\section{c. Mengikuti Berita Aktual Dari Media Pemberitaan}

Update terhadap perkembangan masa kini merupakan suatu tuntutan yang tidak bisa diabaikan. Perkembangan jaman yang semakin modern akan melahirkan permasalahan serta solusi yang baru. Sebagai seorang guru yang baik haruslah dapat mengikuti apa yang terjadi pada lingkungan sekitar maupun masyarakat global agar dapat mengikuti perkembangan siswa dengan baik. Mengetahui model pembelajaran terbaru serta media pembelajaran yang dapat diunakan dalam pembalajaran.

d. Mengikuti Pelatihan

Salah satu cara dalam mengupgrade pengetahuan dan keterampilan adalah mengikuti pelatihan. Pelatihan biasanya diselenggarakan oleh lembaga yang profesional atau instansi terkait yang ditunjuk pemerintah dalam mensosialisasikan suatu kebijakan. Dengan mengikuti pelatihan ini guru dapat menambah keterampilan dalam hubungannya dengan tugas yang sedang diemban. Pelatihan mengenai model pembalajaran atau sosialisasi kurikulum dapat juga diselanggarakan oleh interen sekolah. Kepala sekolah maupun pengawas menjadi pemeteri bagi buru-guru.

Itulah beberapa cara dalam meningkatakan kompetensi pedagogik yang dapat dilakukan oleh guru. namun demikian, kegiatan tersebut di atas haruslah dilakukan secara berkelanjutan. Updating terhadap sesuatu yang bearu haruslah selalu dilakukan guru demi menjaga kualitas dalam menjalankan kewajiban.

\section{KESIMPULAN}

Sebagai seorang guru yang baik dan profesional haruslah memiliki kompetensi yang sesuai dengan profesinya. Terdapat empat ompetensi yang harus dimiliki oleh seorang guru agar menjadi seorang pengajar sekaligus pendidik yang profesional yaitu: kompetensi pedagogik, kompetensi sosial, kompetensi profesional, dan kompetensi kepribadian.

Kompetensi pedagogik merupakan kompetensi yang mutlak dimiliki oleh guru sekaligus kompetensi ini merupakan kompetensi yang membedakan guru dengan profesi lainnya. Kompetensi ini mencakup pengetahuan dan keterampilan yang luas serta mendalam mengenai karakteristik siswa serta psikologi siswa. dengan menguasai kompetensi ini diharapkan guru dapat lebih efektif dan efisien dalm berinteraksi dengan siswa serta dapat memacahakan permasalahan yang terjadi pada siswa.

Agar dapat mengembangkan diri, seorang guru harus selalu mengasah pengetahuan dan keterampilan menganai pembelajaran dan siswa. beberapa cara yang 
dapat dilakukan guru dalam mengasah kemempuannya yaitu: rajin rmembaca bukubuku pendidikan, membaca dan menulis karya tulis ilmiah, mengikuti berita aktual dari media pemberitaan, serta mengikuti pelatihan.

\section{DAFTAR PUSTAKA}

Asmarani, N., 2014. Peningkatan Kompetensi Profesional Guru di Sekolah Dasar. Bahana Manajemen Pendidikan. Jurnal Administrasi Pendidikan. Volume 2 Nomor 1, Juni 2014.

Kusnandar. 2009. Guru Profesional Implementasi Kurikulum Tingkat Satuan Pendidikan (KTSP) dan Sukses dalam Sertifikasi Guru. PT Rajagrafindo Persada. Jakarta.

Meutia, H., Johar, R., Ahmad, A., 2013. Kemampuan Mahasiswa Calon Guru Menerapkan Penilaian Kinerja Untuk Menilai Hasil Belajar Siswa Dalam Pembelajaran Matematika. Jurnal Peluang, Volume 1, N omor 2, April 2013.

Mulyasa, E., 2013. Standar Kompetensi dan Sertifikasi Guru. PT Remaja Rosdakarya. Bandung.

Sari, Z. I., \& Noe, W,. 2014. Hubungan Kompetensi Pedagogik Guru Dengan Kinerja Mengajar Guru di SDIT Nurul Falah Kec. Tambun Utara Kab. Bekasi. Jurnal Pedagogik, Vol. II, No. 1, 2014.

Saud., U., S., 2010. Pengembangan Profesi Guru. Alfabeta. Bandung.

Suprihatiningrum, J. 2014. Guru Profesional : Pedoman Kinerja, Kualifikasi \& Kompetensi Guru. Yogyakarta: Ar-Ruzz Media.

Wahyudi, I. 2012. Panduan Lengkap Uji Sertifikasi Guru. PT.Prestasi Pustakarya. Jakarta. 